\title{
Differences in Entrepreneurial Orientation (EO) of SMEs in the International Context: Evidence from the Czech Republic and Turkey
}

\author{
Aleksandr Kljucnikov ${ }^{1}$, Mehmet Civelek $^{2}$, Gentjan Cera ${ }^{3}$, Jiri Mezulanik ${ }^{4}$, Radim Manak ${ }^{5}$ \\ ${ }^{1,2,4}$ University of Entrepreneurship and Law.Institute of Entrepreneurship and Marketing \\ Vltavska 585/14, 150 00, Prague, Czech Republic \\ E-mail. ${ }^{1}$ kliuchnikov@gmail.com ; ${ }^{2}$ m_civelek@windowslive.com; ${ }^{4}$ jiri.mezulanik@vspp.cz \\ ${ }^{3}$ Tomas Bata University in Zlin \\ Mostni 5139, 76001 Zlin, Czech Republic \\ E-mail.cera@utb.cz. \\ ${ }^{5}$ College of Entrepreneurship and Law plc \\ Vltavska 585/14, 15000 Praha 5, Czech Republic \\ E-mail.radim.manak@vspp.cz.
}

cross $^{\text {ref }}$ http://dx.doi.org/10.5755/j01.ee.31.3.23933

\begin{abstract}
Although SMEs make significant contributions to socio-economic conditions of countries, they face many financial, organizational and mercantile obstacles in their operations. In this regard, having more innovative, risk-taking and proactive activities (EO) increases SMEs' performance, financial conditions and help them to survive in the long term. Therefore, finding regional, national and international differences in EO of SMEs can enable policymakers, financing institutions, SMEs, and entrepreneurs to create more opportunities for SMEs to overcome those problems. In this regard, this research seeks to explore the differences between entrepreneurial orientation (EO) of SMEs that operate in different regions of countries with various cultural values, income levels, economic, political and legal risks. Moreover, age and size of firms are also considered to find differences among SMEs in national and international contexts. In line with these objectives, the current study examines two different countries that have cultural differences and have different economic, legal and political risks. To achieve the objectives, 1620 Czech and Turkish SMEs were analyzed by performing the MannWhitney U and Moran's I spatial autocorrelation tests. According to the results of Moran's I autocorrelation test, this research does not find any differences between the low and high-income regions of the selected countries regarding EO of SMEs. Experience and age of the respondents might be the reason for these results. Significant results in the national context are that EO of SMEs does not differ across the age categories, while there are differences between firm size and their EO. In the international context, the main findings are that Czech SMEs are more proactive than Turkish ones in all age and size categories, while Turkish SMEs are more innovative in all age categories and only in small size segment. However, this research has not revealed any differences within the risk-taking behaviour of SMEs from different countries considering their size and age. The significant differences and similarities in EO of SMEs from different countries might stem from the educational status of the respondents, a considerable number of operating firms in a market, agility, flexibility, $R \& D$ activities and sector of firms. Financial, educational, administrative and legislative support needs to be given by policymakers to close the gap between EO of SMEs of different age, size, regions and countries.
\end{abstract}

Keywords: SMEs; Entrepreneurial Orientation; Czech Republic; Turkey; Age; Innovativeness; Risk-Taking; Proactiveness.

\section{Introduction}

The important role of SMEs in the creation of labour and the formation of added value over the years leads to the fact that they are an essential part of the economy. Most of SMEs face difficulties to survive and to grow in the long term due to the existence of unstable market conditions, financing obstacles and lack of valuable assets. In this regard, the current research considers a substantial determinant factor of the strategic making process of SMEs, namely, entrepreneurial orientation (EO) that helps SMEs to overcome the constraints of their survival.

Miller (1983) is the first researcher who has named the concept of EO and focused on innovative businesses that take hazardous initiatives and act proactively seeking potential market opportunities for their product or services and gain competitive advantages against their competitors. That is why many scholars who considered Miller's (1983) definitions determine and conceptualize innovativeness, risk-taking behaviour and proactiveness as EO dimensions (Covin \& Slevin, 1989; Rauch et al., 2009; Wiklund \& Shepherd, 2005). For that reason, this study uses innovativeness, risk-taking behaviour and proactiveness to evaluate EO of SMEs.

EO enables firms to develop and generate new products and services by applying new technologies and production methods. Therefore, EO is also closely related to engineering innovation that plays an active role in firms' economic growth, development and survival. EO also increases firms' management abilities to make better 
decisions for their operations and also has a positive effect on SMEs in terms of generating income, seizing opportunities in the market and fulfilling customers' needs.

Many empirical studies also declare that entrepreneurial orientation is positively associated with growth (Kljucnikov et al., 2019), success (Glodowska et al., 2019), performance (Muriithi et al., 2018), market share (Jelenc et al., 2015) and internationalization of firms (Glodowska et al., 2019; Wach et al., 2018). SMEs are an essential element in the development of the economies of countries around the world (Onuferova \& Cabinova, 2018) so their significant contribution to the economy of the Czech Republic and Turkey can not be overlooked. The percentages of SMEs in terms of added value in the Czech Republic and Turkey are $54.4 \%$ and $53 \%$ respectively. When it comes to the generation of workforce, both countries have similar percentages, ranging from $72.1 \%$ to $73 \%$ (EC Annual Report on European SMEs, 2016/2017; European Commission SBA Fact sheet for Turkey, 2017).

According to these statistics, it may seem that the SMEs of these countries make the same socio-economic contribution. Still, their entrepreneurial activity will vary depending on the size, age and region in which the SME operates. This is because legal (Semrau et al., 2016; Chowdhury \& Audretsch, 2014), economic (FernandesSerrano \& Romero, 2013; Dvoulety, 2017; Abrham et al., 2015), and political risks, as well as cultural differences (Kreiser et al., 2010; Hofstede et al., 2010), affect SMEs' EO differently in various countries.

In this regard, this paper will consider the number of loans for SMEs, GDP per capita, and credit ratings of various nations to investigate the impact of economic conditions on EO of SMEs. Moreover, this paper takes into consideration the Global Competitiveness index to evaluate the quality of legal requirements in those selected nations. Political Risk Index and Corruption Perceptions Index will be discussed to examine the political conditions of the Czech Republic and Turkey. Hofstede's dimensions for cultural differences such as Masculinity-Femininity, IndividualismCollectivism, Power Distance and Uncertainty Avoidance will be considered in this paper to find impacts of cultural factors on EO of SMEs.

Concerning the characteristics of SMEs, firm size and age are examined. The reason why this study considers both variables is that age and size of firms are substantial determinant factors for EO of firms since they influence success and financial power of enterprises (Islam et al., 2011). By analyzing Czech SMEs Zapletalova (2012) finds positive influences of age and size of SMEs on their internationalization. Moreover, positive impacts of age (Laforet, 2013; Islam et al., 2011) and size (Pett \& Wolf, 2012; Islam et al., 2011; Anderson \& Eshima, 2013) on EO have been substantiated by many studies.

This study contributes to several areas. Analyzing and comparing EO of SMEs from different countries that have different cultural values and face various economic, legal and political risks can contribute to the development of academic literature. Moreover, as far as is known, regional differences in EO of SMEs from different countries have not been analyzed by other studies. Although some studies investigate international differences of EO (Filser \& Egger, 2014; Kreiser et al., 2010), they do not consider the countries represented in this study. The entrepreneurial activity of SMEs deserves thorough research in the regional, national and international context that has been done in this study. The obtained data on EO of SMEs in different countries distinguish this study from existing studies in the entrepreneurial literature. For these reasons, academicians, policymakers, governments, national and institutional organizations, banks and other institutions can gain benefits from the results of this study. They can apply some regulations or activities to improve conditions of SMEs to make them more innovative, risk-taking and proactive. EO is highly correlated with the performance of firms, and increased profitability of SMEs causes better economic conditions for different nations.

Within this context, the goal of the current research is to investigate and find out regional, national and international differences in EO of SMEs regarding their age and size. The main aim of this paper is to evaluate whether financial, legal and political requirements and cultural differences of various countries influence the EO of SMEs. Thus, the research questions are the following: Do firm size and age positively influence EO of SMEs? Does EO of SMEs differ in case of operating in low income or high-income regions? How do political, legislative, and economic conditions as well as cultural differences of nations affect EO of SMEs?

In order to compare national and international differences of EO of SMEs, the research applies MannWhitney tests. When it comes to comparisons in the regional context, Moran's I Spatial Autocorrelation Test is performed. According to the European Commission (2003), SMEs are divided into three segments based on the number of workers as follows: micro enterprises have up to 9 employees; small enterprises have less than 50 employees; the maximum number of employees for medium-sized companies is 250 . The analyzed countries also use this definition to categorize SMEs. The description of the Family Business Institute (2019) is used in this research to categorize firms in terms of firms' age. For instance, according to the Family Business Institute, firms are young if they are less than ten years old.

The rest of the paper is organized as follows. Next section introduces the background of this study by providing information from valuable sources in the entrepreneurship literature. In section 3, methods and research data that this study applies are provided. Section 4 reveals the results of this study, while section 5 discusses them and gives some reasons for them by comparing our findings with other studies. In the concluding section, the research is briefly summarized, and some governmental implementations are offered.

\section{Literature Review}

EO involves strategic activities that improve business' competencies to take innovative, proactive actions and risks in uncertain conditions that can cause possible losses (Covin \& Slevin, 1989; Shirokova et al., 2016). Innovativeness refers to the ability of firms to generate new ideas, to create new products and services or maintain existing product and services by focusing on research, development, technical and technological methods or activities (Rauch et al., 2009; 
Lumpkin \& Dess, 1996). Innovation also increases the SMEs' performance providing profit growth and competitive advantage, hence, they can gain opportunities to become market leaders (Laforet, 2013). Some studies analyzing Czech (Zapletalova, 2012) and Polish (Kowalik et al., 2017) SMEs indicate a reduction in internationalization time due to innovativeness.

When a company invests in projects with a high probability of failure or uncertain income, it is at risk. (Covin \& Slevin, 1989). Risk-taking behaviour indicates how firms are ready to invest money in their activities and projects with undefined incomes under uncertain market conditions (Lumpkin \& Dess, 1996; Miller, 1983). Enterprises are disposed to take risks to gain higher incomes; thus this risk-taking behaviour can define businesses' incomes (Laukkanen et al., 2013; Acar \& Goc, 2011). The third dimension of EO is proactiveness. It enables firms to discover market opportunities and gaps by taking some initiatives (Rauch et al., 2009). Thus, it makes businesses to be different from their rivals and gain competitive advantages by acting as a first-mover (Rauch $e t$ al., 2009; Lumpkin \& Dess, 1996; Filser \& Eggers, 2014; Laukkanen et al., 2013).

Pett and Wolf (2012) highlight that when a firm becomes larger, its executives might be willing to discover and penetrate new markets and try to draw clients' attention. Thus, they can take more risks, be more innovative and proactive. Larger enterprises have more resources, assets and financial opportunities than microenterprises. Hence, due to a lack of financial power, micro firms are more likely to face business failure, that makes them encounter more difficulties to survive than larger businesses. Similarly, Kowalik et al. (2017) state that due to having more financial and physical sources, larger firms perform better in innovativeness. Moreover, Acar and Goc (2011) and Petrakis (2005) also state that smaller firms are less likely to take risks than bigger ones. By considering above mentioned empirical results, this paper expects the fact that larger enterprises are more innovative, risk-taking and proactive in comparison with smaller businesses.

Regarding impacts of firm age on EO, Wiklund and Shepherd (2005) and Rosenbusch et al. (2011) verify significant influences of firm age on EO. Sekliuckiene et al. (2017) also highlight that age affects entrepreneurial attitudes. In this context, Laforet (2013) analyzed around 1000 SMEs in the UK and found that older companies are more innovative than younger companies. Similarly, Sorensen and Stuart (2000) highlight that older businesses are more prone to apply more innovative activities than their younger counterparts since they are more informed about market conditions and entrepreneurial activities. By examining Japanese SMEs, Anderson and Eshima (2013) also find that firm age has positive impacts on EO. When SMEs get older, they improve their EO. Therefore, this study assumes the fact that older enterprises behave more innovatively, proactively and have more tendencies to take risk comparing to younger SMEs.

Region context. The regions in which SMEs operate play a crucial role for SMEs' EO. In this regard, Audretsch et al. (2015) posit that entrepreneurial activities differ regarding regions. Fernandes-Serrano and Romero (2013) and Dvoulety (2017) also support the fact that firms located in high-income areas carry out more innovative and proactive activities than SMEs in low-income regions. Similarly, Abrham et al. (2015) elucidate that SMEs in high-income regions have more EO than SMEs in low-income regions. Since low-income regions have lack of sources to perform innovative activities, they have more obstacles to compete with other firms (FernandesSerrano \& Romero 2013).

International context. A strand of literature confirms the differences among EO of SMEs in an international context. For instance, Colvin and Slevin, (1991) and Kreiser et al. (2010) state that the legislative environment and competitiveness in the market impact risk-taking, proactive, and innovative attitudes. Semrau et al. (2016) remark SMEs are more likely to perform better in countries that have achieved institutional development more than other countries that are less institutionally developed. Moreover, operating in a hostile environment makes businesses to behave more innovatively, proactively and makes them to take risky actions, while operating in a benign environment makes firms to behave more conservatively regarding EO (Laukkanen et al., 2013; Covin \& Slevin, 1989). In this regard, The Global Competitiveness Index is an important indicator to pay attention to. It measures the competitiveness of countries, quality of their public institutions, regulations of states to indicate how countries are productive and efficient (Belanova, 2014).

Regarding economic conditions in various countries, Filser et al. (2014) examined businesses in Austria and Hungary and confirmed that firms with more financial sources perform better in EO dimensions. Furtermore, Kokacinska and Puziak (2018) investigate R\&D expenses of Slovakia, Poland, Hungary and the Czech Republic and find that the Czech Republic has made more investments in R\&D. Kreiser et al. (2010) also state that GDP per capita, have significant and different influences on risk-taking and proactive behaviours of SMEs from different countries. Concerning political risk and their impacts on EO of SMEs, political risk affects risk-taking and proactive behaviours of SMEs from different countries (Kreiser et al., 2010).

Corresponding to cultural differences, according to Hofstede et al. (2010), they are individualism, power distance, masculinity and uncertainty avoidance. According to Hofstede (2010), SMEs executives from countries with lower uncertainty avoidance have more tendency to take risks and innovative actions. Similarly, Mueller and Thomas (2001) also highlight that entrepreneurs in a country with lower uncertainty avoidance are more likely to be proactive than entrepreneurs from a country with higher uncertainty avoidance. In their study, Kreiser et al. (2010) also prove the fact of the negative relationship between the level of uncertainty avoidance in a country and EO of SMEs. Some studies also confirm the fact that managers in a state with masculine culture and low power distance are more prone to take risks and behave more proactively (Hoftsede, 2010; Kreiser et al., 2010).

\section{Methodology and Procedures}

Influenced by prior studies (Wiklund \& Shepherd, 2005; Pett \& Wolf, 2012), evaluating EO, seven survey questions in five-point Likert type scale were chosen. The validity and reliability analyses of selected survey questions were also performed by some studies (Belas \& Sopkova, 2016; Kljucnikov et al., 2016; Kozubikova et al., 2016). The 
respondents of those surveys were the executives of the firms', such as owners, shareholders and managers of SMEs. Respondents were interviewed on behalf of the company they own or work for. They were asked to think about the responses in terms of firms.

Three following survey questions were used to measure innovativeness of SMEs: inno 1 "My company has a reputation as an innovator", inno 2 "We regularly develop new products and services in my company", inno 3 "We invest a lot of money into the development of new methods and technologies." Regarding risk-taking behaviour, two statements were directed to the respondents: rit1 "My firm follows a strategy that I perceive considerably risky" and rit2 "The firm carries out risky projects to increase the performance". Proactiveness was examined by these indicators: pro1 "Our company is often the initiator of actions to which competitors are forced to respond." and pro2 "We seek to exploit predicted changes in our target market ahead of our competitors".

According to studies that were presented in the literature review section regarding the size, age, and EO of SMEs, the researchers formulate the following hypotheses:

H1: Firm size is positively correlated with innovativeness (H1a), risk-taking behaviour (H1b) and proactiveness (H1c).

$\mathrm{H} 2$ : Firm age is positively associated with innovativeness $(\mathrm{H} 2 \mathrm{a})$, risk-taking behaviour $(\mathrm{H} 2 \mathrm{~b})$ and proactiveness $(\mathrm{H} 2 \mathrm{c})$.

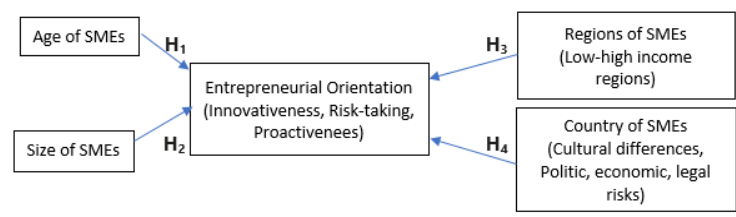

Figure 1. Theoretical Model

Regarding regional income differences and EO of Czech SMEs, GDP in current prices is higher in the following regions of the Czech Republic: Praha, Stredocesky, Jihocesky, Moravskoslezsky, Ustecky, Plzensky and Jihomoravsky than other low-income regions (Czech Statistical Office, 2017). By analyzing Czech SMEs, Abrham et al. (2015) also confirmed the positive impact of location on the competitiveness and profitability of businesses. Czech firms that are located in a well-developed region behave more competitively; thus, they might have better financial performance and more innovative and proactive activities (Abrham et al., 2015; Dvoulety, 2017). In this line, EO of SMEs can show dissimilarities in different regions of the Czech Republic. When it comes to regional differences in EO of Turkish SMEs, low-income regions of Turkey fall behind high-income regions regarding socio-economic factors (Celebioglu \& Dall'erba, 2010; Celebioglu \& Dall'erba, 2010). These low-income regions are specified as Eastern and Southeastern Anatolian regions by many researchers (Celebioglu \& Dall'erba, 2010; Gunerergin et al., 2012; Kilicaslan \& Ozata, 2007). For instance, SMEs that perform their activities in low-income regions of Turkey are more dependent on agricultural activities (Gunerergin et al., 2012). Moreover, low-income regions in Turkey are not only less developed but also receive lower investments and the government's support (Celebioglu \& Dall'erba, 2010; Gunerergin et al., 2012). According to Kilicaslan and Ozata (2007), regional differences in GDP per capita is significant among the regions of Turkey. Since government controls lack in low-income regions of Turkey, the majority of SMEs in those regions face unfair competition (Gunerergin et al., 2012). For these reasons, it can be expected that SMEs in high-income regions might show more EO than SMEs in lowincome regions. By considering the studies mentioned above, this paper formulates the next hypothesis as follows:

H3: SMEs located in high-income areas show more EO than SMEs in low-income regions.

Concerning international differences among EO of SMEs, as stated previously, this paper considers some important indexes and indicators. One of the indicators that might indicate the economic risk of a country, namely, creditworthiness. The Czech Republic has better credit ratings from some important credit rating agencies such as Fitch, Moody's and S\&P in comparison with Turkey's credit ratings (Trading economics 2018, Czechia credit ratings; Fitch AAstable, Moody's A1 positive, S\&P AA- stable. Turkey credit ratings: Fitch $\mathrm{BB}$ negative, Mood's $\mathrm{Ba} 3$ negative, $\mathrm{S} \& \mathrm{P} \mathrm{B}+$ stable). According to OECD (2019), although the total amount of new loans provided for SMEs from 2008 to 2017 is higher in Turkey than Czechia, due to having a lower number of SMEs, Czech SMEs have gained more amount of loans than Turkish SMEs. Other important indexes that influence EO of SMEs are described in Table 1.

Table 1

Country Rankings and Scores from Indexes

\begin{tabular}{|l|c|c|c|c|c|c|c|c|}
\hline Countries & $\begin{array}{c}\text { Ranking of Global } \\
\text { Competitiveness }\end{array}$ & $\begin{array}{c}\text { GDP per } \\
\text { capita }\end{array}$ & $\begin{array}{c}\text { Level of } \\
\text { corruption }\end{array}$ & $\begin{array}{c}\text { Ranking of } \\
\text { Political Risk }\end{array}$ & $\begin{array}{c}\text { Power } \\
\text { distance }\end{array}$ & Masculinity & $\begin{array}{c}\text { Uncertainty } \\
\text { Avoidance }\end{array}$ & $\begin{array}{c}\text { Individual } \\
\text {-ism }\end{array}$ \\
\hline Czechia & 29 & $20.152 \$$ & 59 & 9 & 57 & 57 & 74 & 58 \\
\hline Turkey & 61 & $10.512 \$$ & 41 & 52 & 66 & 45 & 85 & 37 \\
\hline
\end{tabular}

Source: The Global Competitiveness Report, 2018; PRS's Political Risk Index, 2014-2018, Transparency, Org, 2018; Hofstede Index, 2020.

According to the ranking of PRS's Political Risk Index (2014-2018), Turkey has lower rankings than the Czech Republic. Level of corruption in the country is another significant factor that influences the politic risk of countries. In this regard, the score of the Czech Republic is 59, while Turkey's 41, where the top score is 100 in the Corruption Perceptions Index (Transparency, Org, 2018). These scores from Political Risk and Corruption Perception Indexes indicate that Turkey faces more political risk in comparison to the Czech Republic.
Regarding the scores of the Czech Republic and Turkey from power distance, masculinity and uncertainty avoidance indexes Czech SMEs operate in individualistic culture with low power distance and more uncertainty avoidance in comparison with Turkish firms (Hofstede Index, 2020). Regarding cultural differences, the Czech Republic has a higher level of individualism compared to Turkey, which means that society is more autonomous and carries out independent actions. Thus, Czech SMEs can behave more innovatively, proactively, and risk-taking than Turkish SMEs. 
To sum up, the Czech Republic has better rankings and values than Turkey in some indexes regarding political, economic, legal and cultural factors. Due to operating in a more stable market with developed legal institutions, fewer economic and political risks, being an individualistic male society with a small distance of power and lack of uncertainty, it can be assumed that Czech SMEs may be more innovative, proactive and risky than Turkish SMEs. Thus, the last hypothesis in this paper is formulated as follows:

H4: Czech SMEs are more innovative (H4a), risk-taking (H4b) and proactive (H4c) than Turkish SMEs.

Null hypotheses are formulated as follows;

$\mathrm{H} 0$ : There is no positive dependence between firm size and innovativeness, risk-taking and proactiveness.

$\mathrm{H} 0$ : There is no positive dependence between firm age and innovativeness, risk-taking and proactiveness.

H0: SMEs located in high-income areas do not show more EO than SMEs in low-income regions.

H0: Czech SMEs are not more innovative, risk-taking and proactive than Turkish SMEs.

Method. A non-parametric test, namely, the MannWhitney $U$ test was performed to check differences between two countries because the assumptions of t-test were violated. For instance, for the data distribution, the KolmogorovSmirnov test was performed by the researchers. However, it was confirmed that there is no normal distribution. The MannWhitney $\mathrm{U}$ test converts the scores on the continuous variable to ranks across the two groups. The effect size (r) is calculated by dividing the $\mathrm{z}$ value associated with $\mathrm{U}$ statistic by the square root of the sum of sample size in two groups (Field, 2009). The judgment of the effect size was done based on
Cohen's (1988) benchmarks, where small, medium and large effect are $.01, .30$ and .50. This study also applies Moran's I spatial autocorrelation to examine whether differences exist in the views of respondents regarding the location of firms that they work in.

Data and sample profile. The sample of the analysis in the current research are SMEs that operate in the Czech Republic and Turkey. The data collected separately from both countries through different questionnaire surveys. The lists of e-mail addresses of active SMEs were obtained from various chambers of commerce; then samples were selected on the basis of these lists. The researchers applied a stratified random sampling method to choose SMEs from different regions. Thus, strata are based on all geographical areas of the Czech Republic and Turkey. The study indicated the number of firms in the samples, taking into account the share of active SMEs in each region of the total number of SMEs in this country. Random sampling method was applied, then selected potential respondents were contacted by e-mail or by phone. As a result, the researchers collected fulfilled questionnaires from 1141 Czech SMEs and 479 Turkish SMEs.

The numbers of SMEs in regions of the Czech Republic are follows: Jihocesky 61, Jihomoravsky 56, Karlovy vary 53, Kralovehradecky 73, Liberecky 58, Moravskoslezsky 176, Olomoucky 84, Pardubicky 55, Plzensky 81, Praha 108, Stredocesky 75, Ustecky 60, Vysocina 68, Zlinsky 123. The number of SMEs in regions in Turkish sample are: Marmara 185, Aegean 81, Central Anatolia 47, Mediterranean 51, Black Sea 41, Eastern Anatolia 35, South Eastern Anatolia 39. Table 2 illustrates the sample profile for both countries.

Table 2

Sample Profile

\begin{tabular}{|c|c|c|c|c|c|}
\hline & & \multicolumn{2}{|c|}{ Czech } & \multicolumn{2}{|c|}{ Turkey } \\
\hline & & $n$ & Share & $n$ & Share \\
\hline \multirow[t]{4}{*}{ Firm size } & micro & 740 & $64.86 \%$ & 143 & $29.85 \%$ \\
\hline & small & 306 & $26.82 \%$ & 204 & $42.59 \%$ \\
\hline & medium & 95 & $8.33 \%$ & 132 & $27.56 \%$ \\
\hline & Total & 1141 & $100 \%$ & 479 & $100 \%$ \\
\hline \multirow[t]{4}{*}{ Firm age } & less than 5 years & 245 & $21.47 \%$ & 52 & $10.86 \%$ \\
\hline & 5 to 10 years & 191 & $16.74 \%$ & 90 & $18.79 \%$ \\
\hline & more than 10 years & 705 & $61.79 \%$ & 337 & $70.35 \%$ \\
\hline & Total & 1141 & $100 \%$ & 479 & $100 \%$ \\
\hline
\end{tabular}

\section{Results}

In the following paragraphs it is tested whether are or not differences between firms regarding the dimensions of EO. To get in depth and to have a better view over the problem, firstly, it was tested for differences in these dimensions within the country (national context) categorizing firms according to their age and size. Secondly, the same test was performed to investigate for potential differences between countries in three dimensions of EO (international context), again categorized in respect to firm size and firm age. For analysis purposes, firm size was recoded from three into two categories ("micro" and "small \& medium").

In Klaida! Nerastas nuorodos šaltinis. 3 is shown results of Mann-Whitney tests for differences in EO between firm sizes per each country. The test revealed that the perception of Czech SMEs in EO statistically differs between micro and small \& medium-sized firms (see Table 2). Having a close look at mean ranks it can be concluded that, compared to micro firms, small and medium-sized enterprises scored higher on innovativeness $(U=116,372$, $z=-6.078, p<.001)$ and proactiveness $(U=123,355, z=-$ 4.907, $p<.001)$, and lower on risk-taking $(U=138,041, z$ $=-2.005, p=.045)$.

The same test was performed for Turkish SMEs. The only difference between Czech and Turkish respondents' significantly between Turkish micro and small and medium-sized companies $U=23,696, z=-0.240, p>.10$. Besides proactiveness in Turkey, it was found that dimensions of EO statistically significant differed between micro and small \& medium in both countries. answers was found in proactiveness, which did not differ 
Aleksandr Kljucnikov, Mehmet Civelek, Gentjan Cera, Jiri Mezulanik, Radim Manak. Differences in Entrepreneurial...

According to these results, H1a,c which state that positive relationships exist between measurements of EO and firm size are supported for the Czech case. Only $\mathrm{H} 1 \mathrm{~b}$ hypothesis is not supported for Czech and Turkish SMEs since the microenterprises of both countries take more risks comparing to small and medium-sized companies. Moreover, H1c hypothesis for the Turkish case is not supported since the study did not confirm the positive relationship between the size of the company and its activity.

Results of Mann-Whitney test for Differences between Firm Sizes per Each Country

Table 3

\begin{tabular}{|c|c|c|c|c|c|c|c|c|c|}
\hline \multirow[b]{2}{*}{ Country } & \multirow[b]{2}{*}{ Indicator } & \multicolumn{2}{|r|}{$n$} & \multicolumn{2}{|c|}{ Mean rank } & \multirow[b]{2}{*}{$\boldsymbol{U}$} & \multirow[b]{2}{*}{$z$} & \multirow[b]{2}{*}{$p$} & \multirow[b]{2}{*}{$r$} \\
\hline & & micro & small \& medium & micro & small \& medium & & & & \\
\hline \multirow{3}{*}{$\begin{array}{l}\text { Czech } \\
\text { Republic }\end{array}$} & innov & 740 & 401 & 527.76 & 650.80 & 116,372 & -6.078 & 0.000 & 0.180 \\
\hline & ritaking & 740 & 401 & 584.96 & 545.24 & 138,041 & -2.005 & 0.045 & 0.059 \\
\hline & proact & 740 & 401 & 537.20 & 633.38 & 123,355 & -4.907 & 0.000 & 0.145 \\
\hline \multirow[t]{3}{*}{ Turkey } & innov & 143 & 336 & 216.87 & 249.84 & 20,717 & -2.397 & 0.017 & 0.110 \\
\hline & ritaking & 143 & 336 & 260.92 & 231.10 & 21,032 & -2.188 & 0.029 & 0.100 \\
\hline & proact & 143 & 336 & 237.71 & 240.98 & 23,696 & -0.240 & 0.810 & 0.011 \\
\hline
\end{tabular}

Note: $n$ is sample size, $\mathrm{U}$ is Mann-Whitney statistic.

Table 4 reports the results of Mann-Whitney tests for differences in EO concerning firm age per each country. It is confirmed that the perceptions of EO for both Czech and Turkish respondents do not statistically differ between young (less than 10 years on the market) and old companies (more than 10 years on the market) (see Table 4). For these reasons, the study does not support $\mathrm{H} 2 \mathrm{a}, \mathrm{b}, \mathrm{c}$ hypotheses as they expect a positive relationship between firm age and innovativeness, risk-taking behaviour and proactiveness, respectively.

Results of Mann-Whitney test for Differences between Firm ages per Each Country

Table 4

\begin{tabular}{|c|c|c|c|c|c|c|c|c|}
\hline \multirow[b]{2}{*}{ Country } & \multirow[b]{2}{*}{ Indicator } & \multicolumn{2}{|c|}{$n$} & \multicolumn{2}{|c|}{ Mean rank } & \multirow[b]{2}{*}{$\boldsymbol{U}$} & \multirow[b]{2}{*}{$z$} & \multirow[b]{2}{*}{$p$} \\
\hline & & Firm age $<10$ years & Firm age $>10$ years & Firm age $<10$ years & Firm age $>10$ years & & & \\
\hline Czech & innov & 436 & 705 & 557.66 & 579.25 & 147,874 & -1.086 & 0.278 \\
\hline \multirow{2}{*}{ Republic } & ritaking & 436 & 705 & 557.82 & 579.15 & 147,945 & -1.096 & 0.273 \\
\hline & proact & 436 & 705 & 556.77 & 579.8 & 147,485 & -1.196 & 0.232 \\
\hline \multirow[t]{3}{*}{ Turkey } & innov & 142 & 337 & 238.45 & 240.65 & 23,707 & -0.160 & 0.873 \\
\hline & ritaking & 142 & 337 & 243.58 & 238.49 & 23,419 & -0.373 & 0.709 \\
\hline & proact & 142 & 337 & 228.48 & 244.86 & 22,291 & -0.373 & 0.709 \\
\hline
\end{tabular}

Note: $n$ is sample size, $\mathrm{U}$ is Mann-Whitney statistic. The effect size was not calculated, since no significance was found.

Table 4 indicates the results of Moran's I autocorrelation test for the differences in EO of SMEs located in low and high-income regions. Significant results were found only for two indicators regarding one of the statements of both risk-taking (rit2) and proactiveness (pro1) dimensions in the Czech Republic. Although negative spatial autocorrelation exists for pro1, and there is a positive spatial autocorrelation for rit2. Non-significant spatial autocorrelations were found for all statements of innovativeness, and rit1 and pro2. Thus, it can be stated that the respondents' responses to statements "The firm carries out risky projects to increase its performance" and "Our company is often the initiator of actions to which competitors are forced to respond" do not depend on the region where their company operates. Although some significant differences regarding Moran's I spatial autocorrelation exist in high and low-income areas for Czech SMEs, no dimension has significant results for all of its measurements.

The results of spatial autocorrelation for Turkey are shown in Table 5. Significant spatial autocorrelations do not exist for all statements. Therefore, the regards of Turkish respondents about EO are not impacted by the location of firms they work in. In this regard, this study does not support $\mathrm{H} 3$ hypothesis that assumes the differences among EO of SMEs that operate high and lowincome

regions.

Results of Spatial Autocorrelation (Source: Own Processing)

\begin{tabular}{|c|c|c|c|c|c|c|}
\hline \multirow[b]{2}{*}{ Indicator } & \multicolumn{3}{|r|}{ Czech Republic } & \multicolumn{3}{|c|}{ Turkey } \\
\hline & Moran's I & $p$ & Spatial autocorrelation & Moran's I & $P$ & Spatial autocorrelation \\
\hline inno1 & -0.0712 & 0.459 & Nonsignificant & -0.1423 & 0.414 & Nonsignificant \\
\hline inno2 & -0.2631 & 0.119 & Nonsignificant & -0.2849 & 0.318 & Nonsignificant \\
\hline inno3 & -0.2625 & 0.142 & Nonsignificant & 0.0349 & 0.182 & Nonsignificant \\
\hline rit1 & -0.1908 & 0.234 & Nonsignificant & -0.2009 & 0.499 & Nonsignificant \\
\hline rit2 & 0.2560 & 0.013 & Significant, positive, Space autocorrelation & -0.3464 & 0.221 & Nonsignificant \\
\hline pro1 & -0.3437 & 0.046 & Significant, negative, Space autocorrelation & 0.1410 & 0.104 & Nonsignificant \\
\hline pro2 & -0.1165 & 0.422 & Nonsignificant & -0.1795 & 0.486 & Nonsignificant \\
\hline
\end{tabular}


Table 6 Average Values of the Answers from the Regions of the Czech Republic (Source: Own Processing)

\begin{tabular}{|lll|}
\hline Region & rit2 & pro1 \\
\hline Liberecky & $\mathbf{3 . 0 5}$ & 3.52 \\
Ústecky & 2.81 & 3.53 \\
Praha & 2.74 & $\mathbf{3 . 3 9}$ \\
Karlovy Vary & 2.57 & 3.48 \\
Kralovehradecky & 2.89 & 3.56 \\
Stredocesky & $\mathbf{3 . 6 7}$ & 4.00 \\
Plzensky & $\mathbf{2 . 9 6}$ & 3.72 \\
Pardubicky & 2.78 & 3.61 \\
Olomoucky & 2.61 & $\mathbf{3 . 2 9}$ \\
Moravskoslezsky & 2.30 & 3.80 \\
Vysocina & 2.61 & $\mathbf{3 . 4 0}$ \\
Jihocesky & 2.87 & 3.78 \\
Zlinsky & 2.45 & 3.45 \\
Jihomoravsky & 2.79 & 3.62 \\
\hline
\end{tabular}

Table 6 describes the significant results of Moran's I spatial autocorrelation for Czech SMEs in detail. Questionnaires use a five-point Likert-type scale and allow interviewees to choose one answer for the statement out of five possible. A disagreement with statements was demonstrated with 1-"strongly disagree" and 2-"disagree", while an agreement with 4-"agree" and 5-"strongly agree". For answers of respondents who neither agree nor disagree 3-"undecided" was used. All regions of the Czech Republic and Turkey were included to make an evaluation. The values that are presented in the table show the average values of survey participants' responses in each region.
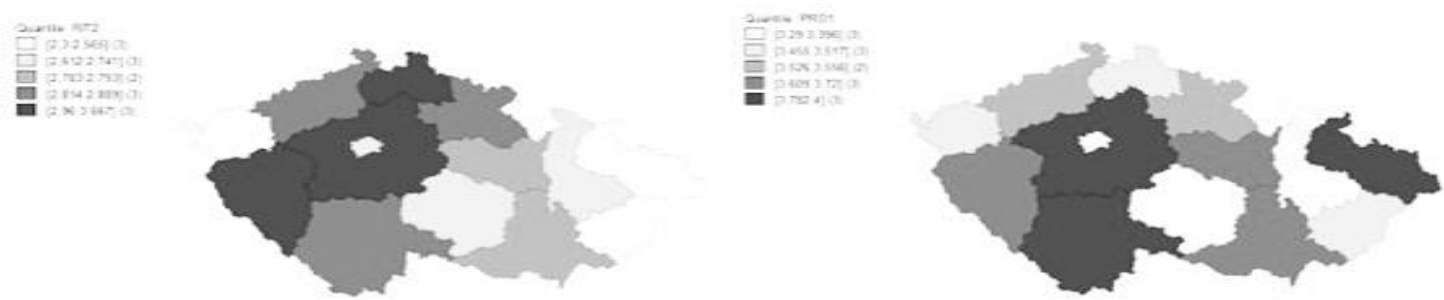

Figure 2. The Findings of Spatial Autocorrelation test for the Czech Republic (Source: Own Processing)

On the left side of Figure 2, spatial autocorrelation results for rit2 statement measurement are provided. The positive autocorrelation for this indicator mainly stems from Liberecky, Stredocesky, and Plzensky regions in the Czech Republic. Most of SMEs in these regions are not prone to agree to the fact that "The firm carries out risky projects to increase the performance". The right side of Figure 2 demonstrates the findings from spatial autocorrelation test for pro1 statement. The significant negative autocorrelation is mostly arising from the following regions: Olomoucky, Praha and Vysocina. A large number of Czech SMEs in these regions agree with the statement that "Our company is often the initiator of actions to which competitors are forced to respond".

The study performs a Mann-Whitney test to answer the question of whether EO of SMEs differs between Czech and Turkish SMEs. Table 7 and Table 8 are provided to show the results of Mann-Whitney tests for EO in two countries for each category of firm size and firm age. According to Table 8, it was found that Czech SMEs were significantly more proactive (micro: $\mathrm{U}=46,566, \mathrm{z}=$ 2.341, p <.05, small: $\mathrm{U}=23,919, \mathrm{z}=-4.612, \mathrm{p}<.001, \mathrm{r}=$ .204; medium: $\mathrm{U}=4,485, \mathrm{z}=-3.746, \mathrm{p}<.001$ ) compared to Turkish SMEs . On the other hand, small enterprises in Turkey were more innovative $(\mathrm{U}=27,868, \mathrm{z}=-2.068, \mathrm{p}<$ .05) compared to Czech ones. No significant difference between the two countries was found in the risk-taking dimension of EO in any category of firm size. On the other hand, there was not found any significant difference in innovativeness between Czech and Turkish micro and medium-sized enterprises.

Results of Mann-Whitney test for Differences between Counties for Each firm Size Category

\begin{tabular}{|c|c|c|c|c|c|c|c|c|c|}
\hline \multirow[b]{2}{*}{ Firm size } & \multirow[b]{2}{*}{ Indicator } & \multicolumn{2}{|c|}{$n$} & \multicolumn{2}{|c|}{ Mean rank } & \multirow[b]{2}{*}{$\boldsymbol{U}$} & \multirow[b]{2}{*}{$z$} & \multirow[b]{2}{*}{$p$} & \multirow[b]{2}{*}{$r$} \\
\hline & & Czech Republic & Turkey & Czech Republic & Turkey & & & & \\
\hline \multirow[t]{3}{*}{ micro } & innov & 740 & 143 & 439.97 & 452.52 & 51,406 & -0.543 & 0.587 & 0.018 \\
\hline & ritaking & 740 & 143 & 438.82 & 458.44 & 50,559 & -0.863 & 0.388 & 0.029 \\
\hline & proact & 740 & 143 & 450.57 & 397.63 & 46,566 & -2.341 & 0.019 & 0.079 \\
\hline \multirow[t]{3}{*}{ small } & innov & 306 & 204 & 244.57 & 271.89 & 27,868 & -2.068 & 0.039 & 0.092 \\
\hline & ritaking & 306 & 204 & 262.78 & 244.58 & 28,985 & -1.401 & 0.161 & 0.062 \\
\hline & proact & 306 & 204 & 279.33 & 219.75 & 23,919 & -4.612 & 0.000 & 0.204 \\
\hline \multirow[t]{3}{*}{ medium } & innov & 95 & 132 & 120.58 & 109.27 & 5,645 & -1.293 & 0.196 & 0.086 \\
\hline & ritaking & 95 & 132 & 115.62 & 112.83 & 6,116 & -0.321 & 0.748 & 0.021 \\
\hline & proact & 95 & 132 & 132.79 & 100.48 & 4,485 & -3.746 & 0.000 & 0.249 \\
\hline
\end{tabular}


Aleksandr Kljucnikov, Mehmet Civelek, Gentjan Cera, Jiri Mezulanik, Radim Manak. Differences in Entrepreneurial...

Note: $n$ is sample size, $U$ is Mann-Whitney statistic.

Results of Mann-Whitney test for Differences between Counties for Each Firm Age Category

Table 8

\begin{tabular}{|c|c|c|c|c|c|c|c|c|c|}
\hline \multirow[b]{2}{*}{ Firm age } & \multirow[b]{2}{*}{ Indicator } & \multicolumn{2}{|l|}{$n$} & \multicolumn{2}{|c|}{ Mean rank } & \multirow[b]{2}{*}{$U$} & \multirow[b]{2}{*}{$z$} & \multirow[b]{2}{*}{$p$} & \multirow[b]{2}{*}{$r$} \\
\hline & & Czech Republic & Turkey & Czech Republic & Turkey & & & & \\
\hline \multirow[t]{3}{*}{ less than 10 years } & innov & 436 & 142 & 281,07 & 315,38 & 27,281 & -2.144 & 0.032 & 0.089 \\
\hline & ritaking & 436 & 142 & 290,59 & 286,16 & 30,482 & -0.281 & 0.779 & 0.012 \\
\hline & proact & 436 & 142 & 303,07 & 247,84 & 25,040 & -3.517 & 0.000 & 0.146 \\
\hline \multirow[t]{3}{*}{ more than 10 years } & innov & 705 & 337 & 505,53 & 554,91 & 107,534 & -2.495 & 0.013 & 0.077 \\
\hline & $\begin{array}{l}\text { ritaking } \\
\end{array}$ & 705 & 337 & 531,38 & 500,82 & 111,825 & -1.569 & 0.117 & 0.049 \\
\hline & proact & 705 & 337 & 546,32 & 469,58 & 101,296 & -3.971 & 0.000 & 0.123 \\
\hline
\end{tabular}

Note: $n$ is sample size, $\mathrm{U}$ is Mann-Whitney statistic.

Table 8 illustrates the results for each category of firms age (less and more than 10 years old). The test showed that Czech entrepreneurs were significantly more proactive (less than 10 years: $\mathrm{U}=25,040, \mathrm{z}=-3.517, \mathrm{p}<$ .001 ; more than 10 years: $\mathrm{U}=101,296, \mathrm{z}=-3.971, \mathrm{p}<$ .001) compared to Turkish once. These results are in line with those received in the firm size case. Conversely, in comparison to Czech SMEs, SMEs operating in Turkey were more innovative in both age categories (less than 10 years: $\mathrm{U}=27,281, \mathrm{z}=-2.144, \mathrm{p}<.05$; more than 10 years: $\mathrm{U}=107,534, \mathrm{z}=-2.495, \mathrm{p}<.05)$. Similar to the case of firm size, no significant difference between the two countries was found in the risk-taking dimension of EO in any category of firm age. Corresponding with the presented results in Table 6 and Table 7, H4a and H4b hypotheses that suppose innovativeness and risk-taking behaviour of Czech SMEs are higher than their Turkish counterparts are not supported. However, Czech SMEs are more proactive than Turkish SMEs in all age and size categories, thus $\mathrm{H} 4 \mathrm{c}$ hypothesis that assumes the fact that Czech SMEs are more proactive than Turkish is supported. Although, Turkish SMEs operate in a country with higher economic, political and legal risk, in a culture with more collectivist, feminine society, higher power distance and uncertainty Turkish firms perform better in innovativeness than their Czech counterparts in all age and size categories. As stated previously, no significant differences exist between Czech and Turkish SMEs in risk-taking dimension even in various age and size categories. Table 9 shows the outcomes of hypotheses testing.

Table 9

Hypotheses Testing Results

\begin{tabular}{|l|l|}
\hline Hypotheses & \multicolumn{1}{|c|}{ Outcomes } \\
\hline H1: Firm size is positively associated to innovativeness (H1a), risk taking (H1b) and proactiveness (H1c). & $\begin{array}{l}\text { H1a, H1c supported. } \\
\text { H1b not supported. }\end{array}$ \\
\hline H2: Firm age is positively associated to innovativeness (H2a), risk taking (H2b) and proactiveness (H2c). & Not supported. \\
\hline H3: SMEs located in high income areas have more EO than SMEs in low-income regions. & Not supported. \\
\hline H4: Czech SMEs are more innovative (H4a), risk taker (H4b) and proactive (H4c) than Turkish SMEs. & $\begin{array}{l}\text { H4a, H4b not supported. } \\
\text { H4c supported. }\end{array}$ \\
\hline
\end{tabular}

\section{Discussion}

The results of this research regarding firm size and EO show that Czech small and medium-sized companies are more innovative and proactive than microenterprises. When it comes to SMEs from Turkey, small and mediumsized enterprises are more innovative than micro firms. These results are compatible with the studies of Pett and Wolff (2012), and Kowalik et al. (2012) as these researchers support the fact that larger firms behave more innovatively comparing to smaller ones. However, there are no significant differences between Turkish micro and small \& medium-sized firms regarding their proactiveness. About 2.7 million SMEs are operating in the Turkish market (OECD Report, 2019). Thus, competition between rival firms could make microenterprises more proactive than mid-sized firms.

On the other hand, micro-enterprises in both countries take more risks than small \& medium-sized enterprises. These results contradict with the findings of Acar and Goc (2011) and Petrakis (2005) that confirm larger enterprises are more risk-averse than smaller ones. According to Laforet (2013), smaller firms can make technological changes in a shorter period than larger firms; thus, they are more focused on research and development activities. In this manner, micro-enterprises in this research have taken more risks to increase their $\mathrm{R} \& \mathrm{D}$ activities. Therefore, Czech and Turkish micro-enterprises considered in this study are riskier than large enterprises in these countries.

Moreover, this research didn't find significant differences between firm age and EO in a national context. This result is contrasted with results of Sorensen and Stuart (2000), Anderson and Eshima (2012) Sekliuckiene et al. (2017), and Laforet (2013) that confirm the dependence between the age of SMEs and its EO. The reason for this result may be the level of education of respondents leaders of SMEs. For instance, $73 \%$ of the respondents in younger Turkish SMEs have at least a bachelor's degree. Regarding the level of education of Czech SME leaders, the percentage of more educated respondents is higher in young firms than in old ones. Thus, more educated executives might be well informed about how to be more innovative, proactive and risk-taking in their business operations. Perhaps due to this fact, the gap within EO of 
young and old firms is closed, and there are no significant differences between them. Positive influences of education on EO have also proved by some studies (Altinay et al., 2011). Moreover, Anderson and Eshima (2013) and Laforet (2013) explain that due to the reduction of a large number of procedures and routine work, young companies are more flexible and can respond more quickly to changing conditions and customer requests. Thus, in this study, the entrepreneurial activity of young enterprises is similar to that of older firms.

Concerning EO of SMEs that operate in low and highincome regions, this study did not find any differences among EO dimensions. Thus, this research differs from the studies of Dvoulety (2017) and Abrham et al. (2015) that verify regional differences in EO of SMEs. The reason why this paper finds no differences in EO of SMEs that are located in different regions might be related to the age of the respondents. The positive relationship between the age of entrepreneurs and EO has also supported by some researches (Jelenc et al., 2015; Brunow and Hirte, 2006). $42 \%$ of the Czech respondents in this research is more than 45 years old. On the other hand, this percentage for entrepreneurs in low-income regions is $52 \%$. Since most entrepreneurs in low-income areas are old, they might act entrepreneurially; therefore, they can be as innovative, proactive and risk-taker as the entrepreneurs of highincome regions of Czech Republic.

Regarding differences in low and high-income regions of Turkey regarding EO dimensions, this research does not find any discrepancies between EO of Turkish SMEs, although Celebioglu and Dall'erba (2010) and Gunerergin et al. (2012) highlight differences among SMEs operating in diverse regions of Turkey. On the other hand, this study has similar results with Canbaz et al. (2013) that analyze potential entrepreneurs in different areas of Turkey and confirm that those entrepreneurs' perceptions regarding entrepreneurial behaviour and attitudes do not differ. Experienced executives are the reason why this research does not find any differences for SMEs in low-income regions of Turkey. Positive influences of experience on EO of SMEs have also confirmed by Jelenc et al. (2015) and Altinay et al. (2011). In this research, approximately $74 \%$ of respondents in low-income regions of Turkey have more than ten years of experience. Thus, the presence of experienced managers makes small and medium-sized enterprises in low-income regions as innovative, risk-taking and proactive as companies in high-income areas of Turkey.

Concerning international differences between innovativeness of SMEs, small Turkish companies are more innovative than Czech ones. But innovativeness of micro and medium-sized Turkish and Czech firms does not differ. Moreover, Turkish SMEs are more innovative than Czech SMEs in each age category. These results object to the findings of Semrau et al. (2016), Kreiser et al. (2010), Hofstede et al. (2010) and Filser et al. (2014) since these studies claim that individualistic, masculine countries with developed institutions, more financial sources, less power distance, and less risk of uncertainty are more innovative. The sectoral differences might be the reason why small Turkish enterprises and younger and older Turkish SMEs are more innovative than Czech ones. For instance, $51.4 \%$ of Turkish SMEs operate in the manufacturing sector, while only $23.1 \%$ of Czech SMEs operate in this area. When it comes to small size enterprises, $56.4 \%$ of Turkish firms perform their activities in the manufacturing industry, while the percentage for Czech businesses is around $35 \%$. Firms in the manufacturing industry are more prone to create new products or develop their existing goods through innovative activities. Having more firms operating in this sector might enable Turkish small-sized, younger and older SMEs to be more creative than their Czech counterparts.

Regarding risk-taking behaviour, no differences between Czech and Turkish SMEs have been confirmed by this research in both firm size and age. This result contradicts with the findings of Ruiz-Ortega et al. (2013), Kreiser et al. (2010), Hofstede et al. (2010) as they confirm dissimilarities in risk-taking behaviour of SMEs from countries with different cultural values. The reason why no differences exist in risk-taking might be related to the education level of Turkish firms' executives. People who have higher education are more capable of evaluating risks than lower-educated individuals (Petrakis, 2005). This fact might have made Turkish SMEs have similar risk-taking behaviours with Czech SMEs although Czech SMEs operate in an advanced economy. $78 \%$ of Turkish respondents have at least a bachelor's degree, while this percentage for Czech respondents is $34 \%$ in the research data. Having more educated Turkish respondents might be the reason for no differences in risk-taking.

Regarding proactiveness in both countries, Czech SMEs are more proactive than Turkish not only in all size categories (micro, small and medium) but also in all age categories. These results regarding proactiveness are compatible with the studies of Adler (1997), and Filser and Eggers (2014) since these studies state that SMEs performing in countries with lower economic, political and legal risks are more proactive than SMEs that face more political, economic and legal risks.

\section{Conclusion}

The results of this research regarding the size of firms and their EO confirm that larger firms perform better in innovativeness than smaller firms. Concerning risk-taking behaviour and firm size, a negative relationship between firm size and risk-taking behaviour was proved. Although a positive relationship between proactiveness and firm size was corroborated in the Czech case, in the case of Turkey, proactiveness does not depend on firms' size. The paper confirmed the absence of a significant relationship between the age of the firm and its EO. Concerning EO of SMEs that operate in low and high-income regions, EO of SMEs does not differ.

Regarding international comparisons in EO dimensions, Czech SMEs are not as innovative as Turkish SMEs. Concerning comparing SMEs in risk assessment, it has been proven that there are no differences between SMEs in selected countries. Thus, risk-taking and innovative behaviours of SMEs are not related to economic, political, legal conditions and cultural differences of various countries. On the other hand, SMEs in a country with lower political, legal and financial risks, low uncertainty avoidance, with masculine and 
individualistic society behave more proactively than another country with opposite characteristics.

To minimize these differences among countries, governments can design and apply some strategies dealing with business activity. For instance, although European Union gives financial, legislative, educational and administrative supports for innovative firms by COSME and Horizon 2020 programs, more funding options might be offered by policymakers to different countries with different financial, legal and political conditions and cultural values. These financial supports can make them to participate fairs and workshops, to access new information technologies that firms can use in their operations to improve their innovative activities. Firms having new creative and proactive ideas become able to apply to international and national patents and licenses that make them gain competitive advantages against their rivals.

Governments can collaborate with universities, development agencies, municipalities, national and international financing organizations to increase the quality of the business environment of SMEs. Moreover, educational programs regarding EO can be given by this collaboration to expand awareness of SMEs regarding the importance of EO for their businesses. All these policies mentioned above can be applied by countries to increase performance, income, credibility, and profitability of SMEs and make SMEs more risk-taking, innovative and proactive.

Although this research investigates considerable amounts of factors that might impact EO of SMEs, it has some limitations. This study only considers three measurements of EO and SMEs from the Czech Republic and Turkey. This study focuses only on features such as SMEs' age and size. The extended construct of EO with autonomy and competitive aggressiveness can be considered by further studies to get more comprehensive research. Moreover, researchers can examine other characteristics SMEs such as legal structure and sectors and include larger size enterprises in their analyses. To provide more extensive research for entrepreneurial literature, authors should include more countries and firms in their studies.

\section{Acknowledgement}

This work was supported by the KEGA Project No. 005SPU-4/2019, "Theory and practice of international management and business in a multicultural environment".

\section{References}

Abrham, J., Strielkowski, W., Vosta, M., \& Slajs, J. (2015). Factors That Influence The Competitiveness Of Czech Rural Small And Medium Enterprises. Agric. Econ - Czech, 61(10), 450-460. https://doi.org/10.17221/63/2015AGRICECON

Acar, E., \& Goc, Y. (2011). Prediction of Risk Perception by Owners' Psychological Traits in Small Building Contractors. Construction Management and Economics, 29(8), 841-852. https://doi.org/10.1080/01446193.2011.611521

Altinay, L., \& Wang, C., (2011), The Influence of an Entrepreneur's Socio-Cultural Characteristics on the EO of Small firms. Journal of Small Business and Enterprise Development, 18(4), 673-694. https://doi.org/10.1108/ 14626001111179749

Anderson, B. S., \& Eshima, Y. (2013). The Influence of Firm Age and Intangible Resources on the Relationship between EO and Firm Growth Among Japanese SMEs. Journal of Business Ventures, 28, 413-429. https://doi.org/10. 1016/j.jbusvent.2011.10.001

Audretsch, D. B., Belitski, M., \& Desai, S. (2015). Entrepreneurship and Economic Development in Cities. The Annals of Regional Science, 55(1), 33-60. https://doi.org/10.1007/s00168-015-0685-X

Belanova, K. (2014). Komparacia kvality podnikatel'ského prostredia v krajinach Vysehradskej stvorky s osobitnym akcentom na dostupnost' fi nancnych zdrojov. Biatec, 1, 12-17.

Belas, J., \& Sopkova, G. (2016). A model of entrepreneurial orientation. Transformations in Business and Economics, 15(2), 630-644.

Canbaz, M., Cankır, B., \& Cevik, E., (2013). Isletme ve Muhasebe Eğitimi Alan Universite Ogrencilerinin Girsimcilik Ozelliklerinin Belirlenmesinde Bolgesel Farklılık Etkisi. Uluslararası Ísletme ve Yonetim Dergisi, 1(3). $229-248$. https://doi.org/10.15295/bmij.v1i3.76

Celebioglu, F., \& Dall'erba, S. (2010). Spatial Disparities across The Regions of Turkey: An Exploratory Spatial Data Analysis. Ann Reg Sci, 45, 379-400. https://doi.org/10.1007/s00168-009-0313-8

Chowdhury, F., \&Audretsch, D. B., (2014). Institution as Looting Apparatus: Impact of Gender Equality and Institutions of the Female Entrepreneurship. Euro Asian Business Review, 4, 207-225. https://doi.org/10.1007/s40821-014-0008-7

Cohen, J. (1988). Statistical power analysis for the behavioral sciences. Hillsdale, NJ: Erlbaum

Covin, J. G., \& Slevin, D. P. (1989). Strategic Management of Small Firms in Hostile and Benign Environments. Strategic Management Journal, 10(1), 75-87. https://doi.org/10.1002/smj.4250100107 
Czech Statistical Office (2017), GDP in current prices. Accessed: 27.06.2019. Retrieved from: http://apl.czso.cz/pll/ rocenka/rocenka.presmsocas

Dvoulety, O. (2017). Can Policy Makers Count With Positive Impact Of Entrepreneurship On Economic Development Of The Czech Regions? Journal of Entrepreneurship in Emerging Economies, 9(3), 286-299. https://doi.org/10. 1108/JEEE-11-2016-0052

European Commission, (2016/2017). Annual Report On European SMEs, Focus self-employment [Online] , Accessed: 10.06.2019, Retrieved from: https://ec.europa.eu/docsroom/documents/26563/attachments/1/translations/en/.../native

European Commission (2003). Recommendation Of 6 May 2003 Concerning The Definition Of Micro, Small And Medium-Sized Enterprises (Text with EEA relevance) (notified under document number C(2003) 1422). Accessed: 28.06.2019

European Commission, SBA fact sheet Turkey, (2017). Accessed: 08.06.2019. Retrieved from: https://ec.europa.eu/ neighbourhood - enlargement/sites/near/files/turkey_sba_fs_2017.pdf

Family Business Institute (2019). Definition of Young Firm. Accessed: 07.06.2019 Retrieved from: https://www.familybusinessinstitute.com/

Fernandez-Serrano, J., \& Romero, I. (2013). Entrepreneurial Quality and Regional Development: Characterizing SME Sectors In Low Income Areas. Papers In Regional Science, 92(3), 495-513. https://doi.org/10.1111/j.14355957.2012.00421.x

Field, A. (2009). Discovering Statistics Using SPSS. Sage Publications, 2009, Third Edition.

Filser, M., Eggers, F., Kraus, S., \& Malovics, E. (2014). The Effect Of Financial Resource Availability On EO, Customer Orientation And Firm Performance In An International Context: An Empirical Analysis From Austria And Hungary. JEEMS, 19(1), 7-30. https://doi.org/10.5771/0949-6181-2014-1-7

Filser, M., \& Eggers, F. (2014). EO And Firm Performance: A Comparative Study of Austria, Liechtenstein and Switzerland. S.Afr.J.Bus.Manage, 45(1), 55-65. https://doi.org/10.4102/sajbm.v45i1.117

Glodowska, A., Maciejewski, M., \& Wach, K. (2019). How Entrepreneurial Orientation Stimulates Different Types of Knowledge in the Internationalisation Process of Firms from Poland?. Entrepreneurial Business and Economics Review, 7(1), 61-73. https://doi.org/10.15678/EBER.2019.070104

Gunerergin, M., Penbek, S., \& Zaptcioglu, D. (2012). Exploring the Problems and Advantages of Turkish SMEs for Sustainability. 8th International Strategic Management Conference, Social and Behavioral Sciences, 58, 244-251. https://doi.org/10.1016/j.sbspro.2012.09.998

Hofstede, G., Hofstede, G. J., \& Minkov, M. (2010), Cultures and Organizations: Software of the Mind-Intercultural Cooperation and Its Importance for Survival, McGraw-Hill.

Hofstede Individualism, Power distance, Uncertainty Avoidance, Masculinity Indexes (2020).Accessed:08.03.2020 https://www.hofstede-insights.com/product/compare-countries/

Islam, A. M., Khan, A. M., Obaidullah, M. Z. A., \& Alam, N. S., (2011). Effect of entrepreneur and firm characteristics on the business success of SMEs in Bangladesh. International Journal of Business and Management, 6(3), 289-299. https://doi.org/10.5539/ijbm.v6n3p289

Jelenc, L., Pisapia, J., \& Ivanusic, N., (2015). Demographic Variables Influencing Individual EO And Strategic Thinking Capability, "10th International Scientific Conference on Economic and Social Development," Miami.

Kilicaslan, Y., \& Ozata, G. (2007). Impact of Relative Population Change On regional Income Convergence: Evidence From Turkey, RURDS, 19(3), https://doi.org/10.1111/j.1467-940X.2007.00135.x

Kljucnikov A., Belas, J., Kozubikova, L., \& Pasekova, P. (2016). The Entreprenurial Perception of SME Business Environment Quality in the Czech Republic. Journal of Competitiveness, 8(1), 66-78. https://doi.org/10.7441/joc.2016.01.05

Kljucnikov, A., Civelek, M., Cech, P., \& Kloudova, J. (2019). Entrepreneurial orientation of SMEs' executives in the comparative perspective for Czechia and Turkey. Oeconomia Copernicana, 10(4), 773-795. https://doi.org/10. 24136/oc.2019.035

Kokocinska, M., \& Puziak, M. (2018). Regional Income Differences and their Evolution after EU Accession. The Evidence from Visegrad Countries. Journal of Competitiveness, 10(4), 85-101. https://doi.org/10. $7441 /$ joc.2018.04.06 
Kowalik, I., Danik, L., Kral, P., \& Rezankova, H. (2017). Antecedents of Accelerated Internationalisation of Polish and Czech Small and Medium-sized Enterprises. Entrepreneurial Business and Economics Review, 5(3), 31-48. https://doi.org/10.15678/EBER.2017.050302

Kozubikova, L., Belas, J., Kljucnikov, A., \& Virglerova, Z. (2015). Differences in approach to selected constructs of entrepreneurial orientation in SME segment regarding the selected socio-demographic factors. Transformations in Business and Economics, 14(3), 333-355.

Kreiser, P. M., Marino, L. D., Dickson, P., \& Weaver, K. M. (2010). Cultural Influences on EO: The Impact of National Culture on Risk Taking and Proactiveness in SMEs. Entrepreneurship Theory \& Practice, 959-984. https://doi.org/10.1111/j.1540-6520.2010.00396.x

Laforet, S. (2013). Organizational Innovative Outcomes in SMEs: Effects of Size, Age and Sector. Journal of World Business, 48, 490-502. https://doi.org/10.1016/j.jwb.2012.09.005

Laukkanen, T., Nagy, G., Hirvonen, S., Reijonen, H. \& Pasanen, M. (2013). The Effect of Strategic Orientations on Business Performance In SMEs. International Marketing Review, 30(6), 510-535. https://doi.org/10.1108/IMR-092011-0230

Lumpkin, G. T. \& Dess, G. G. (1996). Clarifying the EO Construct and Linking It to Performance. Academy of Management Review, 21(1), 135-172. https://doi.org/10.5465/amr.1996.9602161568

Miller, D. (1983). The correlates of entrepreneurship in three types of firms. Management Science, 29(7), 770-791. https://doi.org/10.1287/mnsc.29.7.770

Mueller, S. L,. \& Thomas, A. S. (2001). Culture and entrepreneurial potential: A nine country study of locus of control and innovativeness. Journal of Business Venturing, 16(1), 51-75. https://doi.org/10.1016/S0883-9026(99)00039-7

Muriithi, R. W., Kyalo, T., \& Kinyanjui, J. (2018). Assessment of the relationship between entrepreneurial orientation, organisational culture adaptability and performance of Christian faith-based hotels in Kenya. International Journal of Entrepreneurial Knowledge, 7(1), 31-45. https://doi.org/10.2478/ijek-2019-0003

OECD (2019). Financing SMEs and Entrepreneurs: An OECD Scoreboard. Accessed: 08.06.2019. Retrieved from https://www.oecd-ilibrary.org/industry-and-services/financing-smes-and-entrepreneurs-2019_

Onuferova, E., \& Cabinova, V. (2018). Enterprise Performance Analysis of the Selected Service Sector by Applying Modern Methods with an Emphasis on the Creation and Application of the Modified Creditworthy Model. Journal of Tourism and Services 9(17). https://doi.org/10.29036/jots.v9i17.74

Petrakis, P. (2005). Risk Perception, Risk Propensity and Entrepreneurial Behavior: The Greek Case. Journal of American Academy of Business, 7(1), 233-42.

Pett, T. M., \& Wolff, J. A. (2012). SME Identity and Homogeneity - Are There Meaningful Differences Between Micro, Small, and Medium-Sized Enterprises? Journal of Marketing Development and Competitiveness, 6(2).

PRS, Political Risk Index (2014-2018). Accessed: 09.06.2019. Retrieved from: https://www.prsgroup.com/regionalpolitical-risk-index-4/

Rauch, A., Wiklund, J., Lumpkin, G. T., \& Frese, M. (2009). EO and Business Performance: An Assessment of Past Research and Suggestions for the Future. Entrepreneurship Theory and Practice, 33(3), 761-787. https://doi.org/10.1111/j.1540-6520.2009.00308.x

Rosenbusch, N., Brinckmann, J., \& Bausch, A., (2011). Is Innovation Always Beneficial? A Meta-Analysis Of The Relationship Between Innovation And Performance In SMEs. Journal of Business Venturing, 26, $441-457$. https://doi.org/10.1016/j.jbusvent.2009.12.002

Ruiz-Ortega, M. J., Parra-Requena, G., Rodrigo-Alarcon, J., \& Garcia-Villaverde, P. M. (2013). Environmental Dynamism and EO. The Moderating Role of Firm's Capabilities. Journal of Organizational Change Management, 26(3), 475-493. https://doi.org/10.1108/09534811311328542

Sekliuckiene, J., Jarosinski, M., \& Kozma, M. (2019). Entrepreneurial Level Factors of Early Internationalization: A Cross Country Comparison. Inzinerine Ekonomika-Engineering Economics, 30(2), 223-235. https://doi.org/10.575 5/j01.ee.30.2.21185

Semrau, T., Ambos, T., \& Kraus, S. (2016). EO and SME Performance across Societal Cultures: An International Study. Journal of Business Research, 69, 1928-1932. https://doi.org/10.1016/j.jbusres.2015.10.082

Shirokova, G., Bogatyreva, K., Beliaeva, T., \& Puffer, S. (2016). EO and Firm Performance in Different Environmental Settings: Contingency And Configurational Approaches. Journal of Small Business and Enterprise Development, 
23(3), 703-727. https://doi.org/10.1108/JSBED-09-2015-0132

Sorensen, J. B., \& Stuart, T. E., (2000). Aging, Obsolescence, And Organizational Innovation. Administrative Science Quarterly, 45, 81-112. https://doi.org/10.2307/2666980

The Global Competitiveness Report (2018). Insight Report The Global Competitiveness Report, Professor Klaus Schwab Editor, World Economic Forum.

Trading Economics, Czechia and Turkey Credit Ratings (2018), Accessed: 08.06.2019. Retrieved from https://tradingeconomics.com/czech-republic/rating, https://tr.tradingeconomics.com/turkey/rating

Transparency International, Corruption Perception Index (2018). Accessed: 08.08.2019 Retrieved from: https://www.transparency.org/cpi2018

Wach, K., Glodowska, A., \& Maciejewski, M. (2018). Entrepreneurial Orientation, Knowledge Utilization and Internationalization of Firms. Sustainability, 10. https://doi.org/10.3390/su10124711

Wiklund, J., \& Shepherd, D. (2005). EO and Small Business Performance: A Configurational Approach. Journal of Business Venturing, 20(1), 71-91. https://doi.org/10.1016/j.jbusvent.2004.01.001

Zapletalova, S. (2012). The Factors Influencing the Internationalization Process Management of Czech Entrepreneurial Subjects. International Journal of Management, 2(7), 21-29.

The article has been reviewed. Received in July 2019; accepted in June 2020. 